\title{
Diet and faecal flora in the newborn: breast milk and infant formula
}

\author{
S E BALMER AND B A WHARTON \\ Sorrento Maternity Hospital, Birmingham
}

SUMmaRY This study examined the faecal flora on days 4,14 , and 28 of 17 breast fed babies and 26 bottle fed babies receiving a modern infant formula based on demineralised whey. Generally among breast fed babies bifidobacteria and staphylococci were the predominant organisms, whereas in the formula fed babies the predominant organisms were enterococci, coliforms, and clostridia. Despite the extensive modification of cows' milk to make an infant formula resemble human breast milk, the results are very similar to those previously reported with unmodified cows' milk baby feeds. The exact dietary factor responsible for these microbiological differences is unclear and in succeeding papers we have looked at the effects of protein quality, in particular the content of whey proteins, casein, and lactoferrin.

For many years it was accepted that the faecal flora of a breast fed baby differed from that of a bottle fed one. ${ }^{1}$ There are three reasons for re-examining this association between diet and faecal flora in the newborn. Firstly, many of these studies were performed using infant formulas that consisted of cows' milk with only minimal modification, whereas cows' milk is now extensively modified in the manufacture of an infant formula. ${ }^{2}$ Secondly, breast milk differs from cows' milk and cows' milk based formula in so many ways it is impossible to know which dietary difference is responsible for the microbiological difference. Thirdly, some studies have not found these differences: the faecal flora of breast and bottle fed babies were similar. ${ }^{34}$ It was suggested that the antiseptic environment of modern obstetrics may have over-ridden the dietary effects.

For these reasons we have re-examined the association between diet and faecal flora. This first paper determines whether the faecal microflora of the breast fed baby differs from that of a bottle fed baby receiving a well defined modern infant formula and succeeding studies explore the effects of specific nutrients.

\section{Subjects and methods}

DIET AND BABIES (TABLES 1 AND 2)

The infant formulas most commonly used in early life are based on demineralised whey plus skimmed milk, a blend of vegetable and animal fats, vitamins,
Table 1 Composition of feeds compared with unmodified cows' milk (perl)

\begin{tabular}{llll}
\hline & $\begin{array}{l}\text { Breast } \\
\text { milk }\end{array}$ & $\begin{array}{l}\text { Modern whey } \\
\text { formula }\end{array}$ & $\begin{array}{l}\text { Unmodified } \\
\text { cows' milk }\end{array}$ \\
\hline $\begin{array}{l}\text { Protein g } \\
\quad \text { (nitrogen } \times 6.38)\end{array}$ & 11 & 17 & 33 \\
$\begin{array}{l}\text { Total 'true' } \\
\text { protein (\%) }\end{array}$ & $9(100)$ & $16(100)$ & $31(100)$ \\
$\quad$ Caseins & $2.5(28)$ & $6.4(40)$ & $24.5(79)$ \\
$\quad$ Whey proteins & $6.5(72)$ & $9.6(60)$ & $6.5(21)$ \\
$\begin{array}{l}\text { Phosphorus (mg) } \\
\text { Iron (mg) }\end{array}$ & 150 & 340 & 950 \\
& 0.76 & 8.00 & 0.50 \\
\hline
\end{tabular}

Table 2 Data of babies taking part in the study

\begin{tabular}{lcc}
\hline & $\begin{array}{l}\text { Breast fed } \\
(n=17)\end{array}$ & $\begin{array}{l}\text { Formula fed } \\
(n=26)\end{array}$ \\
\hline Sex: & 8 & 12 \\
$\quad$ Male & 9 & 14 \\
$\quad$ Female & & \\
Race: & 15 & 19 \\
$\quad$ White & 0 & 6 \\
$\quad$ Asian & 2 & 1 \\
$\quad$ Afro-Caribbean & 1 & 10 \\
$\begin{array}{l}\text { Born by caesarean section } \\
\text { Mean (SD) birth weight (g) }\end{array}$ & $3330(390)$ & $3290(530)$ \\
$\begin{array}{l}\text { Mean (SD) weight gain } \\
\text { day 1-day 28 (g) }\end{array}$ & $770(340)$ & $810(330)$ \\
\hline
\end{tabular}


and minerals including iron. We therefore used such a formula (Nan supplied by Nestlé) for one group of babies, the other group was breast fed. Allocation of the babies to the two dietary groups depended solely on the mother's wish to breast or bottle feed her baby and so was not random. The babies in the two groups were similar in mode of delivery, size, etc. All were well and none received antibiotics. Mothers of the breast fed babies did not receive antibiotics postnatally. Breast fed babies were allowed feeds of water between breast feeds and the use of dummies was not prohibited.

\section{PROCEDURES}

Both groups of babies were fed on demand. The formula was reconstituted by the project nurses until the babies were 14 days old. From day 14 to day 28 mothers reconstituted the powdered formula. Anthropometric measurements were made at days 1 and 28. Faeces were collected on days 4,14 , and 28 .

\section{MICROBIOLOGICAL METHODS}

Faeces were collected in nappy liners, weighed and emulsified in a transport medium (BHI broth containing $10 \%$ glycerol and $0.03 \%$ sodium formaldehyde sulphoxalate). This was immediately frozen and stored at $-20^{\circ} \mathrm{C}$. All specimens were analysed within one month of collection. Eight 10 fold dilutions were made in transport medium, and $20 \mu \mathrm{l}$ of each dilution were inoculated in triplicate on to MacConkey agar (for enterobacteriaceae, Staphylococcus spp, and Enterococcus spp), Rogosa agar (for Lactobacillus spp and Bifidobacterium spp), and Blood agar containing $\mathbf{0 . 0 1 \%}$ neomycin (for Clostridium, Bacteroides, and Bifidobacterium spp). Bacteria were identified by standard methods outlined by Cowan. ${ }^{5}$ API20E were used to identify enterobacteriaceae, API20A were used to identify anaerobes (API System SA). Lactobacillus spp were identified using API50CHL. Bifidobacterium spp were identified biochemically using API50CHL as media and comparing the profiles with those of reference species of bifidobacteria obtained from the National Institute of Research in Dairying, Shinfield and to the schemes drawn up by Holdeman, Cato, and Moore and Mitsuoka and Kaneuchi. ${ }^{67}$

\section{FAECAL PH}

The $\mathrm{pH}$ of each faeces sample was measured in a $10 \%$ suspension in normal saline. All measurements were taken in a single batch using a Bibby 3 in 1 stick meter with an SMP 1 electrode.

\section{STATISTICAL ANALYSIS}

The results were analysed statistically using MannWhitney, Wilcoxon, $\chi^{2}$ (with Yates's correction), and McNemar (with Yates's correction) tests as appropriate.

\section{ETHICAL APPROVAL}

Approval for the study was obtained from the ethics committee of the South Birmingham Health Authority. The mothers of all babies taking part in the study gave written informed consent.

\section{Results}

\section{MICROBIOLOGY}

There is no accepted convention for presenting descriptions of faecal flora. We found difficulty in summarising the data (for example, as means and SDs, etc) without covering up details of the distribution. We have therefore chosen to present the results in two ways: (1) counts of individual organisms in each baby shown diagrammatically; these were analysed statistically by Mann-Whitney, Wilcoxon, and $\chi^{2}$ tests. (2) patterns of dominance in individual babies (that is, a particular genus accounting for the highest count in the bacterial population examined); these were analysed by $\chi^{2}$ and McNemar tests.

(1) Counts of individual organisms (figs 1 and 2)

(a) Changes with time-The faecal flora changed with time but more changes were seen in the formula fed babies. Significant changes in the number of babies colonised are shown in columns marked y:

(i) breast fed babies had an increase in coliforms other than Escherichia coli but a decrease in enterococci;

(ii) formula fed babies had an increase in $E$ coli, enterococci, and lactobacilli but a decrease in staphylococci.

Significant changes in the counts of organisms are shown in columns marked $\mathrm{x}$ :

(i) breast fed babies had an increase in staphylococci and bifidobacteria;

(ii) formula fed babies had increase in $E$ coli, enterococci, bifidobacteria, and clostridia.

(b) Dietary differences-More breast fed babies were colonised with staphylococci but fewer with clostridia (columns marked b).

Breast fed babies had lower counts $E$ coli coliforms, enterococci, and clostridia but higher counts of staphylococci (columns marked a).

(c) Mode of delivery-Only one breast fed baby was delivered by caesarean section but 10 formula fed babies were delivered by section. None of the 10 babies were colonised by bacteroides on either day 4 

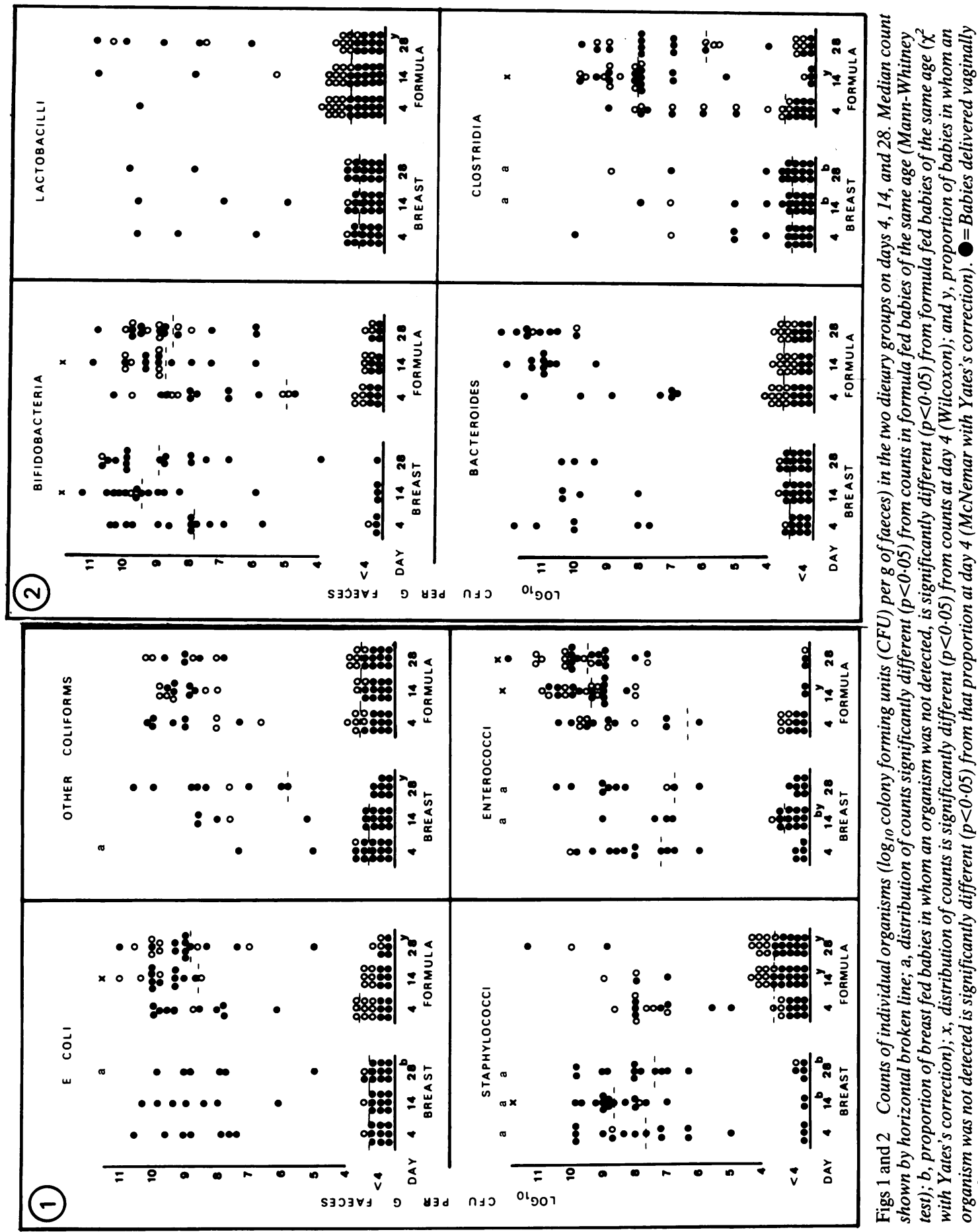

흥 
Diet and faecal flora in the newborn: breast milk and infant formula 1675
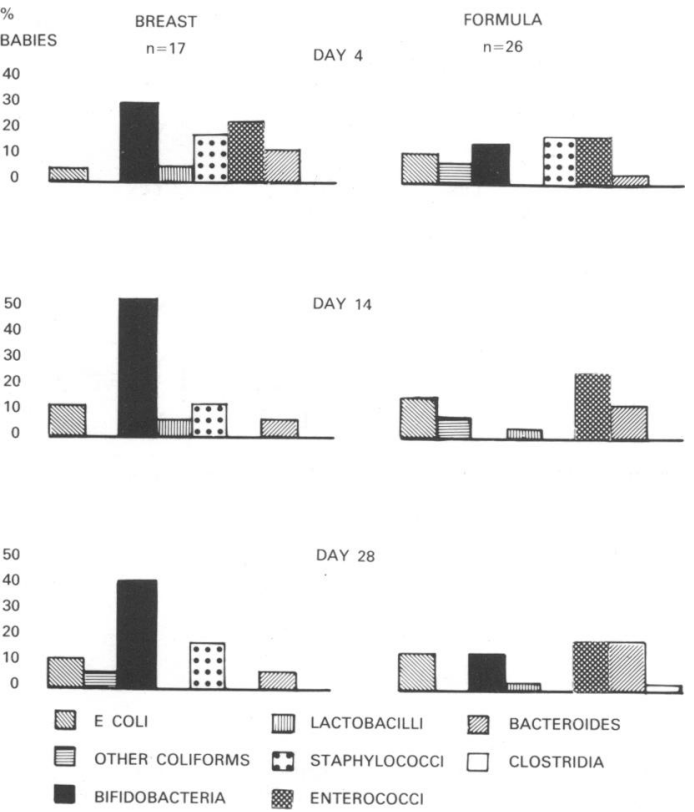

Fig 3 Percentage of babies in whose faeces organisms were dominant.

or day 14. Of the 16 vaginally born formula fed babies, however, seven were colonised with bacteriodes on day $4(\mathrm{p}<0.02)$ and 10 by day 14 $(\mathrm{p}<0 \cdot 001)$.

(2) Patterns of dominance (fig 3)

(a) Changes with time-Enterococci were not dominant in any breast fed baby at days 14 or 28 and staphylococci were not dominant in any formula fed baby at days 14 and 28 .

(b) Dietary differences-At day 4 no difference was observed. Later at day 14, when compared with breast fed babies, none of the formula fed babies had bifidobacteria as the dominant organism $(\mathrm{p}<0.001)$ and more had enterococci dominant, although this was not significant. This trend was continued at day 28 with an increased number of

Table 3 Mean $(S D)$ pH of faeces

\begin{tabular}{lll}
\hline & Breast fed & Formula fed \\
\hline Day 4 & $5 \cdot 56(0.35)$ & $5.90(0 \cdot 79)$ \\
Day 14 & $5.49(0 \cdot 40)^{*}$ & $6.91(0.80)^{*} \dagger$ \\
Day 28 & $5.74(1.03)^{*}$ & $7.07(0.94)^{*} \dagger$ \\
\hline
\end{tabular}

${ }^{*}$ Difference between breast and formula fed babies $p<0.001$.

†Significant difference between value on day 4 . breast fed babies with bifidobacteria as the dominant organism, but it was no longer significant.

FAECAL PH (TABLE 3)

The $\mathrm{pH}$ of the breast fed babies was always more acidic than the formula fed babies and this was highly significant at days 14 and 28 . The $\mathrm{pH}$ of the breast fed babies did not change significantly during the study but that of the formula fed babies became less acidic after day 4 .

\section{Discussion}

Generally among breast fed babies bifidobacteria and staphylococci were the predominating organisms (for example, higher counts or more babies colonised or more babies in which the organisms were dominant), whereas in formula fed babies the predominant organisms were enterococci. It does seem therefore that modern infant formulas, despite extensive modification during manufacture, result in a faecal flora substantially different from that of the breast fed baby.

Table 4 summarises the results of this and some previous studies. The nature of the diets used is often not stated. However, like many other investigators we found a predominance of bifidobacteria in the breast fed babies. We are unclear why this was not observed in the babies born at St Bartholomew's Hospital, London. ${ }^{3}$ The suggestion by the authors of that study that the antiseptic environment of modern obstetrics being responsible is an interesting one. In this hospital we use $1.5 \%$ chlorhexidine gluconate and $15 \%$ cetrimide diluted 1:50 (Savlon) for vulval washing and $1 \%$ chlorhexidine gluconate (Hibitane Obstetric cream) for vaginal examinations during labour, but antiseptic nipple sprays are not encouraged.

What are the exact dietary constituents responsible for the observed differences in the faecal flora in the formula and breast fed infant? The substances and mechanisms implicated (casein, phosphate, buffering capacity, lactoferrin, secretory IgA) and the reviews of the subject are legion, ${ }^{16-18}$ but as breast milk differs from an infant formula in so many ways it is difficult to know which is the main factor. In the succeeding papers we have looked at the microbiological effects of specific nutrients: casein and whey proteins, phosphate, lactoferrin, and iron.

This project was partially supported by Nestlé (Nestec Ltd, Research Centre), CH 1800 Vevey, Switzerland. We are grateful to Mrs C Boyle and Mrs N Burton for the preparation of feeds and the collection of specimens. 
Table 4 Comparison of studies examining faecal microflora in breast and formula fed babies. (Results refer to breast fed babies)

\begin{tabular}{|c|c|c|c|c|c|c|c|c|}
\hline Country & $\begin{array}{l}\text { No of } \\
\text { babies }\end{array}$ & $\begin{array}{l}\text { Age of } \\
\text { babies }\end{array}$ & $\begin{array}{l}\text { Type } \\
\text { of milk }\end{array}$ & $\begin{array}{l}\text { Less } \\
\text { coliforms }\end{array}$ & $\begin{array}{l}\text { More } \\
\text { bifidobacteria }\end{array}$ & $\begin{array}{l}\text { Less } \\
\text { enterococci }\end{array}$ & $\begin{array}{l}\text { More } \\
\text { staphylococci }\end{array}$ & $\begin{array}{l}\text { Less bactoides } \\
\text { and clostridia }\end{array}$ \\
\hline \multirow[t]{3}{*}{$\begin{array}{l}\text { United Kingdom } \\
\text { (this study) }\end{array}$} & $\begin{array}{l}17 \\
26\end{array}$ & 4 days & \multirow{3}{*}{$\begin{array}{l}\text { Breast } \\
\text { Nan } \\
\text { Breast } \\
\text { Nan } \\
\text { Breast } \\
\text { Nan }\end{array}$} & No & Yes & Yes & Yes & No \\
\hline & $\begin{array}{l}17 \\
26\end{array}$ & 14 days & & Yes & Yes & Yes & Yes & Yes \\
\hline & $\begin{array}{l}17 \\
26\end{array}$ & 28 days & & Yes & Yes & Yes & Yes & Yes \\
\hline \multirow[t]{5}{*}{ United Kingdom' } & $\begin{array}{r}7 \\
10\end{array}$ & 1 week & $\begin{array}{l}\text { Breast } \\
\text { Cows' milk }\end{array}$ & Yes & Yes & Yes & NT & Yes \\
\hline & $\begin{array}{l}5 \\
4\end{array}$ & 2 weeks & $\begin{array}{l}\text { Breast } \\
\text { Cows' milk }\end{array}$ & No & Yes & Yes & NT & Yes \\
\hline & $\begin{array}{l}7 \\
4\end{array}$ & 3 weeks & $\begin{array}{l}\text { Breast } \\
\text { Cows' milk }\end{array}$ & Yes & Yes & Yes & NT & Yes \\
\hline & $\begin{array}{l}4 \\
3\end{array}$ & 5 weeks & $\begin{array}{l}\text { Breast } \\
\text { Cows' milk }\end{array}$ & Yes & Yes & Yes & NT & Yes \\
\hline & $\begin{array}{l}2 \\
2\end{array}$ & 7 weeks & $\begin{array}{l}\text { Breast } \\
\text { Cows' milk }\end{array}$ & No & Yes & Yes & NT & Yes \\
\hline \multirow[t]{3}{*}{ United Kingdom ${ }^{8}$} & $\begin{array}{l}24 \\
20 \\
20\end{array}$ & $7-10$ days & $\begin{array}{l}\text { Breast } \\
\text { SMA } \\
\text { Cow and Gate } \\
\text { special }\end{array}$ & No & Yes & NT & NT & NT \\
\hline & 10 & & $\begin{array}{l}\text { Cow and Gate } \\
1 / 2 \text { cream }\end{array}$ & & & & & \\
\hline & 4 & & $\begin{array}{l}\text { Golden } \\
\text { Ostermilk }\end{array}$ & & & & & \\
\hline United Kingdom ${ }^{9}$ & $\begin{array}{l}11 \\
21\end{array}$ & 5-7 days & $\begin{array}{l}\text { Breast } \\
\text { SMA } \\
\quad \text { Gold Cap }\end{array}$ & No & Yes & NT & NT & NT \\
\hline \multirow[t]{3}{*}{ United Kingdom ${ }^{10}$} & $\begin{array}{l}9 \\
6\end{array}$ & $1-5$ days & $\begin{array}{l}\text { Breast } \\
\text { Formula* }\end{array}$ & No & Yes & NT & NT & No \\
\hline & $\begin{array}{l}9 \\
6\end{array}$ & 3 weeks & $\begin{array}{l}\text { Breast } \\
\text { Formula* }\end{array}$ & No & No & NT & NT & No \\
\hline & $\begin{array}{l}9 \\
6\end{array}$ & 6 wecks & $\begin{array}{l}\text { Breast } \\
\text { Formula* }\end{array}$ & No & No & NT & NT & No \\
\hline \multirow[t]{3}{*}{ United Kingdom ${ }^{3}$} & $\begin{array}{l}15 \\
11\end{array}$ & 2 weeks & $\begin{array}{l}\text { Breast } \\
\text { Formula* }\end{array}$ & No & No & Yes & Yes & Yes \\
\hline & $\begin{array}{l}16 \\
12\end{array}$ & 4 weeks & $\begin{array}{l}\text { Breast } \\
\text { Formula* }\end{array}$ & No & No & Yes & Yes & Yes \\
\hline & $\begin{array}{l}15 \\
12\end{array}$ & 6 weeks & $\begin{array}{l}\text { Breast } \\
\text { Formula* }\end{array}$ & No & No & Yes & Yes & Yes \\
\hline Nigeria & 12 & & Breast & Yes & Yes & No & No & Yes' \\
\hline \multirow[t]{3}{*}{ Sweden ${ }^{4}$} & $\begin{array}{r}15 \\
7\end{array}$ & 5 days & $\begin{array}{l}\text { Breast } \\
\text { Whey based } \\
\text { formula }\end{array}$ & No & Yes & Yes & Yes & Yes \\
\hline & $\begin{array}{r}15 \\
7\end{array}$ & 3 wecks & $\begin{array}{l}\text { Breast } \\
\text { Whey based } \\
\text { formula }\end{array}$ & Yes & No & Yes & Yes & No \\
\hline & $\begin{array}{r}15 \\
7\end{array}$ & 8 wceks & $\begin{array}{l}\text { Breast } \\
\text { Whey based } \\
\text { formula }\end{array}$ & No & No & No & Yes & No \\
\hline Australia ${ }^{\prime \prime}$ & $\begin{array}{l}7 \\
7\end{array}$ & $\begin{array}{l}1 \text { week } \\
4 \text { weeks }\end{array}$ & $\begin{array}{l}\text { Breast } \\
\text { Formula* }\end{array}$ & Yes & Yes & Yes & NT & Yes \\
\hline Japan $^{12}$ & $\begin{array}{l}70 \\
35\end{array}$ & 28-46 days & $\begin{array}{l}\text { Breast } \\
\text { Formula* }\end{array}$ & Yes & No & Yes & No & Yes \\
\hline \multirow[t]{2}{*}{ Japan $^{13}$} & $\begin{array}{l}6 \\
7\end{array}$ & 1-6 days & $\begin{array}{l}\text { Breast } \\
\text { Cows' milk }\end{array}$ & Yes & Yes & Yes & No & Yes \\
\hline & $\begin{array}{l}6 \\
7\end{array}$ & 4 weeks & $\begin{array}{l}\text { Breast } \\
\text { Cows' milk }\end{array}$ & No & Yes & Yes & No & Yes \\
\hline France $^{14}$ & $\begin{array}{l}22 \\
11\end{array}$ & $1-8$ days & $\begin{array}{l}\text { Breast } \\
\text { Gallia }\end{array}$ & No & Yes & No & NT & No \\
\hline Holland ${ }^{15}$ & $\begin{array}{r}10 \\
6 \\
7\end{array}$ & $1-3$ months & $\begin{array}{l}\text { Breast } \\
\text { Almiron } \\
\text { Almiron- } \\
\quad \text { no added } \\
\text { iron }\end{array}$ & Yes & Yes & Yes & NT & No \\
\hline
\end{tabular}

${ }^{*}$ Formula not specified: NT= not tested. 


\section{References}

${ }^{1}$ Bullen CL, Tearle PV, Willis AT. Bifidobacteria in the intestinal tract of infants-an in vivo study. $J$ Med Microbiol 1976;9:325-33.

2 Wharton BA. Infant formulae. Bulletin British Nutrition Foundation 1984;9:83-93.

${ }^{3}$ Simhon A, Douglas JR, Drasar BS, Soothill JF. Effect of feeding on infants faecal flora. Arch Dis Child 1982;57:54-8.

${ }^{4}$ Lundequist B, Nord CE, Winberg J. The composition of faecal microflora in breast fed and bottle fed infants from birth to 8 weeks. Acta Paediatr Scand 1985;74:45-51.

5 Cowan ST. Manual for the identification of medical bacteria. Cambridge: Cambridge University Press, 1981.

${ }^{6}$ Holdeman LV, Cato EP, Moore WEC. Anaerobe laboratory manual. Virginia: Virginia Polytechnic Institute, 1977.

${ }^{7}$ Mitsuoka T, Kaneuchi C. Ecology of the bifidobacteria. Am J Clin Nutr 1977;30:1799-810.

${ }^{8}$ Hewitt JH, Rigby J. Effects of various milk feeds on numbers of E. coli and Bifidobacterium in the stools of newborn infants. J Hyg (Camb) 1976;77:129-39.

9 Dolby JM, Honour P, Valman HB. Bacteriostasis of E coli by milk. I. Colonisation of breast fed infants by milk resistant organisms. J Hyg (Camb) 1977;78:85-94.

10 Rose SJ. Bacterial flora of breast fed infants. Pediatrics 1984;74:563-4.

11 Stark PL, Lee A. The microbial ecology of the large bowel of breast fed and formula fed infants during the first year of life. $J$ Med Microbiol 1982;15:189-203.

12 Benno Y, Sawada K, Mitsuoka T. The intestinal microflora of infants: composition of fecal flora in breast fed and bottle fed infants. Microbiol Immunol 1984;28:975-86.
${ }^{13}$ Yoshioka H, Iseki K, Fujita J. Development and differences of intestinal flora in the neonatal period in breast fed and bottle fed infants. Pediatrics 1983;72:317-21.

14 Moreau MC, Thomasson M, Ducluzeau R, Raibaud P. Cinetique d'establissement de la microflora digestive chez le nouveau-ne humain en fonction de la nature du lait. Reprod Nutr Dev 1986;26(2B):745-53.

${ }^{15}$ Mevissen-Verhage EAE, Marcelis JH, Harmsen-Van Amerongen WCM, de Vos NM, Verhoef J. Effect of iron on neonatal gut flora during the first three months of life. Eur $J$ Clin Microbiol 1985;4:273-8.

16 Bullen JJ. Role of milk and gut flora in the protection of the newborn against infection. In: Lambert HP, Wood CBS, eds. Immunological aspects of infection in the fetus and the newborn. London: Academic Press, 1981:123-37.

17 Rolles CJ, Hall MA, Duncan H, Sampeys C. Bifidobacteria in breast milk-a review and a hypothesis. In: Wharton BA, ed. Topics in perinatal medicine. Vol 2. Bath: Pitman, 1982:31-47.

18 Wharton BA. Immunological implications to alternatives to mother's milk. 1. Infant formulas. In: Wilkinson AR, ed. Immunology of infant feeding. New York: Plenum Press, 1981:107-22.

Correspondence and requests for reprints to Dr SE Balmer, Milk Bank, Sorrento Maternity Hospital, 15 Wake Green Road, Birmingham B13 9HE.

Accepted 17 April 1989 